\title{
Accelerated Concrete Carbonation and Resulting Rebar Corrosion Under a High Temperature Condition in Nuclear Power Plants
}

\author{
Shiro Mitsugi $^{1 *}$, Eiji Owaki $^{2}$, Hirotaka Masuda $^{3}$ and Ryu Shimamoto ${ }^{4}$
}

\begin{abstract}
To assess the durability of concrete structures at nuclear power plants in Japan, plant life management technical evaluation is performed in accordance with the guidelines of the Architectural Institute of Japan for the maintenance and management of structures in nuclear facilities. Concrete carbonation is one of the degradation factors covered in the guidelines, and sampling is performed to confirm the progression of carbonation and predict future progression. Electricity providers in Japan perform sampling at locations constituting environments (temperature, relative humidity, carbon dioxide concentration) where carbonation progresses relatively fast to confirm that carbonation has not reached the rebars and to predict progression. In this study, accelerated carbonation tests were performed at high temperature, which is believed to accelerate carbonation, considering the parameters of relative humidity. Progression of carbonation and its impact on rebar corrosion were examined. The results showed that progression of carbonation in high-temperature environments can be predicted with a margin of safety using the Architectural Institute of Japan's durability prediction equation. Moreover, because the humidity environments where carbonation progresses and the temperature environments where rebar corrosion progresses do not correspond with each other, rebars are typically unlikely to corrode even if carbonation has reached the rebars, provided they are not subjected to extreme wet-dry cycles.
\end{abstract}

\section{Introduction}

In addition to annual periodic inspections, nuclear power plants in Japan are required by the state to undergo plant life management technical evaluations every 10 years, after 30 years from the start of commercial operation. The plant life management technical evaluation comprises the evaluation of the durability of concrete structures. Durability evaluation of concrete structures is conducted in accordance with the Guidelines for Maintenance and Management of Structures in Nuclear Facilities of the Architectural Institute of Japan (AIJ 2015), hereafter referred to as "Guidelines for Maintenance", which focuses on the following degradation factors: heat (high temperature), irradiation, carbonation, chloride penetration, alkali silica reaction, machine vibration,

\footnotetext{
${ }^{1}$ Acting General Manager, Nuclear Facilities Division, Taisei Corporation, 1-25-1 Nishi-Shinjuku, Shinjuku-ku, Tokyo 163-0606, Japan. *Corresponding author,

E-mail: mitugi@eng.taisei.co.jp

${ }^{2}$ Executive Chief Research Engineer, Taisei Advanced Center of Technology, Taisei Corporation, 344-1, Nase, Totsuka, Yokohama 245-0051, Japan.

${ }^{3}$ Manager, Construction Project Group, Civil \& Architectural Engineering Dept., Shikoku Electric Power Co., Inc., 2-5, Marunouchi, Takamatsu-shi, Kagawa 760-8573 Japan.

${ }^{4}$ Senior Manager, Civil \& Architectural Engineering Department, Nuclear Power Division, Chubu Electric Power Co., Inc., 1, Higashi-Shincho, Higashi-Ku, Nagoya 461-8680, Japan.
}

freeze-thaw, drying shrinkage, creep, insolation, weathering, and traveling motion of vehicles. Concrete carbonation is one of the degradation factors covered in the guidelines.

Electricity providers in Japan take samples from sites that are representative in terms of environments where carbonation progresses relatively quickly (temperature, relative humidity and carbon dioxide concentration), to determine whether carbonation has reached the rebars, and predict progression. Few data are available on the parameter of relative humidity in relation to carbonation and the resulting rebar corrosion in high-temperature environments, where carbonation progression is believed to accelerate. To increase the representative nature of sample-testing-based evaluations, we conducted tests with the objective of obtaining data to facilitate evaluations without the need for sampling in high-temperature environments. Concrete structures in Japanese nuclear power plants are designed to remain below $65^{\circ} \mathrm{C}$ always, in accordance with the Nuclear Reactor Building Structural Design Guidelines. On this basis, we obtained data to facilitate the evaluation of progression of carbonation and rebar corrosion, by considering humidity conditions as the parameters, in high-temperature environments. Rebars were removed from the specimens and subjected to detailed rust measurements. In the accelerated carbonation tests, the test temperature was set at $60^{\circ} \mathrm{C}$ to enable accurate humidity control in the test equipment.

Parrot (1991) reported on the effect of relative humidity on carbonation, where the carbonation was largely controlled by gas diffusion through the empty pores in the exposed surface layer. The level of carbonation through different pore structures was strongly de- 
pendent on the moisture conditions during carbonation. The relative humidity with the maximum carbonation rate varies among studies. Chen et al. (2018) reported that temperature, $\mathrm{CO}_{2}$ concentration, and relative humidity influenced the carbonation depth and compressive strength of concrete significantly, and concrete carbonation depth reached its peak when the relative humidity was 70\%. Leemann et al. (2016) indicated that increasing RH from $57 \%$ to $70 \%$ and $80 \%$ at a $\mathrm{CO}_{2}$ concentration of $4 \%$ decreased the carbonation. Russell et al. (2001) demonstrated that the carbonation rate reached a peak between 55 and 65\% RH. Ceukelaire et al. (1993) showed that the maximum carbonation velocity was observed at the relative humidity level of $50 \%$. Salvoldi (2015) presented model predicting carbonation depth development based on parameters, including environmental exposure (relative humidity and $\mathrm{CO}_{2}$ concentration) and concrete microstructure. Leemann et al. (2016) also reported that the ranking of the different concrete mixtures with regard to carbonation resistance varied, likely due to the w/c and cement-specific pore size distribution. Moreover, Houst (1996) reported that the network of fine pores with a radius of $\leq 0.1$ to $0.5 \mu \mathrm{m}$ is the first of the two levels, where capillary condensation and adsorption could occur, and the diffusion in this network were strongly influenced by the water content. Ceukelaire et al. (1993) reported that their samples appeared to lose a certain amount of their compressive strength due to exposure to normal $\mathrm{CO}_{2}$ concentrations, particularly at higher relative humidity levels; however, the effect caused by a high concentration appeared to be more positive. Liu et al. (2019) reported that the concrete carbonation depth increased with the increase in temperature, whereas the compressive strength of concrete after carbonation decreased with the increase in temperature. This was attributed to the possibility that the $\mathrm{CO}_{2}$ transmission coefficient and chemical reaction coefficient might increase with temperature. Drouet et al. (2019) indicated that high temperature was found to accelerate the carbonation rate although not in the same manner for different pastes. The carbonation rate of one paste increased linearly with temperature between 20 and $80^{\circ} \mathrm{C}$, whereas that of another paste reached a maximum at approximately $50^{\circ} \mathrm{C}$. This disparity was attributed to the differences in the mineralogical assemblage of the two pastes: portlandite and $\mathrm{C} / \mathrm{S}$ ratio.

As outlined above, several studies have been conducted on the impact of temperature and relative humidity on carbonation rate; however, the relative humidity at which the carbonation rate is at its maximum differs among studies. Moreover, thus far, no study has focused on the impact of relative humidity in high-temperature environments.

Huet et al. (2003) reported that the service life of a concrete structure could be divided into two stages, characterized by the rate of corrosion, namely initiation and propagation of active corrosion. In the former, the corrosion rate was significantly low (passive corrosion).
The duration of this stage was determined based on the transport properties of the concrete cover (HR, porosity, and eventually micro-cracks) and the aggressive species $\left(\mathrm{Cl}^{-}, \mathrm{CO}_{2}\right)$ of the environment. Stefanonia et al. (2018) summarized the corrosion rate data for a broad range of cement types, w/b ratios, and environmental conditions. The data showed that the corrosion rate generally increased with increasing clinker replaced binders. The main parameter controlling the corrosion rate of steel in carbonated concrete was the exposure condition, i.e., at low RH the corrosion rate was negligible, and significant values were reported only in significantly humid conditions and in direct contact with water. Correlations between the corrosion rate and the main influencing parameters are elaborated and discussed. It has been confirmed that the corrosion rate of steel in carbonated concrete is not under ohmic control. More important are the degree of pore saturation and the effective steel area in contact with water-filled pores. Ferreira et al. (2015, 2016) indicated that most models were used only for the process of carbonization and chloride penetration and disregarded the corrosion of the reinforcing steel. Their paper presented probabilistic design procedures combining the limit states of corrosion initiation and propagation, where there was a difficulty in the definition of the limit state requirement. Yonezawa et al. (2014) demonstrated that even after carbonation of the concrete, the rebar corrosion rate at a humidity of 40 to $60 \%$ was markedly low and equal to that of passive steel. In environments with high humidity of $95 \%$, the post-carbonation rebar corrosion rates were extremely high at 10 to 50 times the rates at 40 to $60 \%$ humidity. Thus, it was concluded that in outdoor environments that are exposed to rain, corrosion due to the effect of high humidity environments during rainfall is predominant, and a corrosion rate equation for outdoor environments was established based on the corrosion rate equation by introducing a coefficient representing the time ratio at which the high humidity state is effective.

No studies that focus on high-temperature environments in relation to the impact of relative humidity on rebar corrosion are available. Moreover, most existing studies estimated the amount of corrosion using electrochemical methods, whereas few measured corrosion directly by removing the rebars. The present study investigated the impact of relative humidity in high-temperature environments on carbonation and the resulting rebar corrosion. Rebars were removed from the specimens and rebar corrosion was measured in detail. Furthermore, few data exist from studies on continuous corrosion resulting from carbonation over a prolonged period, and this study contributes to the expansion of these data.

\section{Evaluation of carbonation in nuclear power plant concrete}

\subsection{Evaluation of progress of carbonation}

The carbonation of concrete has been intensively studied 
for many years. The Architectural Institute of Japan has systematically gathered the relevant results and included them in their "Guidelines for Maintenance" (AIJ 2015) In aging evaluations in Japan, the carbonation of concrete structures is evaluated as a primary evaluation, which is on the material level in accordance with these guidelines. In a primary evaluation, progression of the carbonation depth is predicted, and if the predicted value is equal to or greater than the concrete cover depth outdoors, or if it exceeds the concrete cover depth by $20 \mathrm{~mm}$ or more indoors, the evaluation proceeds to a secondary evaluation for the effects on the member or structure.

The concrete structures subject to aging evaluations are diverse as shown in Fig. 1. Some of them include places where concrete sampling is difficult.

Typical examples of places where sampling is difficult include the shell wall surrounding the reactor vessel, the reactor containment vessel, the reactor containment vessel basemat, and inside structures, close to the reactor vessel, e.g., the reactor body foundation, the diaphragm floor, and the internal concrete. The concrete in these places is inherently difficult to sample owing to radiation protection (prevention of damage to the shielding materials) and restricted access to the area (reduction of exposure of workers), among other factors. Places where sampling is difficult also include high and confined places, and places at the rear or base of the machinery and equipment. This study examined the evaluation of concrete carbonation in such places.

Concrete carbonation generally progresses faster at higher temperatures, and it is expected that temperatures may rise in the above-mentioned concrete owing to the effects of radiation and other aspects. Concrete structures in nuclear power plants in Japan are designed according to "Recommendations for Structural Design of Reactor
Buildings" (AIJ 1988) for ordinary temperatures not exceeding $65^{\circ} \mathrm{C}$. Considering these factors, this study evaluated the progression of carbonation in a high-temperature environment up to a maximum of $65^{\circ} \mathrm{C}$, taking the humidity as a parameter. In the accelerated carbonation test, the test temperature was set at $60^{\circ} \mathrm{C}$ such that the test equipment can accurately control the humidity.

\subsection{Characteristics of concrete used}

The characteristics of concrete used in nuclear power plants were organized based primarily on published records (Adachi et al. 1993; Fujino 1969; Fujiwara et al. 2008; Hayashi et al. 1972; Horiuchi et al. 1975; Ibaraki et al. 1995; Inoue et al. 1974a, 1974b, 1989; Ishii et al. 1982; Kadoki et al. 2003; Kanamori et al. 1983; Kawahara et al. 2009; Kasaoka et al. 1982; Morishita 1997; Morishita et al. 1998a, 1998b, 1998c; Nakajima et al. 1989; Nomura et al. 1974; Ogawa et al. 2003; Ohno et al. 1974; Otsuka et al. 2004; Shiire et al. 1989; Suzuki et al. 1984; Tanaka et al. 1999, 2006; Tanji et al. 1999; Ueda et al. 1989; Yamamoto et al. 1991; Yonashiro et al. 1986) for plants currently subject to inspections under technical evaluations of aging management. Targeting the 18 commercial power plants in Japan, there are 56 reactors, among which 32 are boiling water reactors (BWR) and 24 are pressurized water reactors (PWR). A total of 104 concrete mixtures could be confirmed.

Figure 2 shows the frequency of the cements used. Fly ash cement type B and a mixture of ordinary Portland cement and fly ash equivalent to fly ash cement were frequently used binders, which accounted for $55 \%$ of the total. All mixtures of ordinary Portland cement and fly ash had a fly ash replacement ratio of $20 \%$, equivalent to fly ash cement type B.

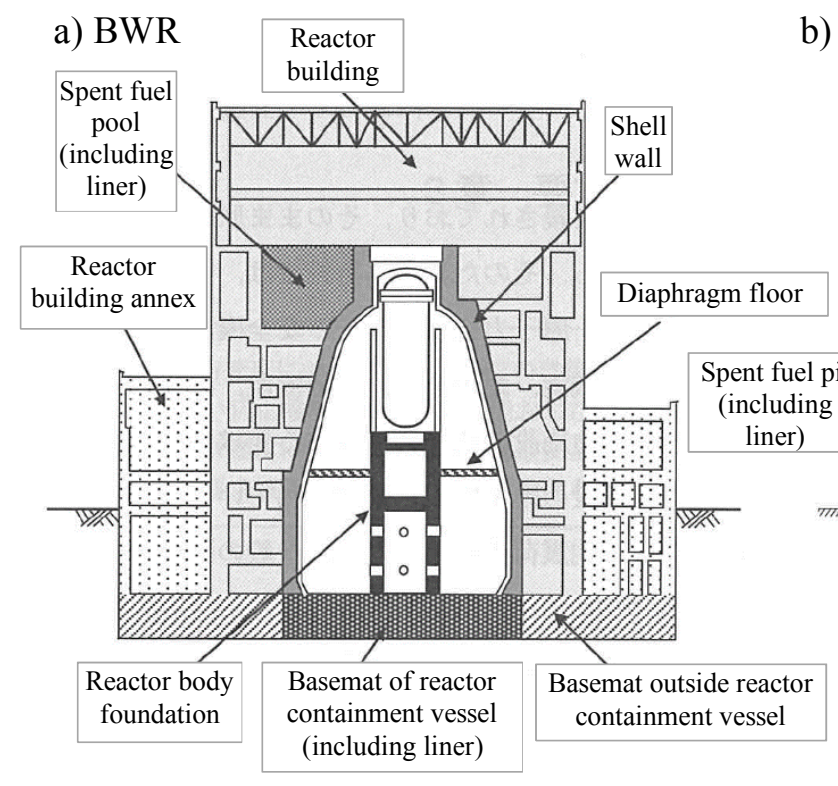

b) PWR

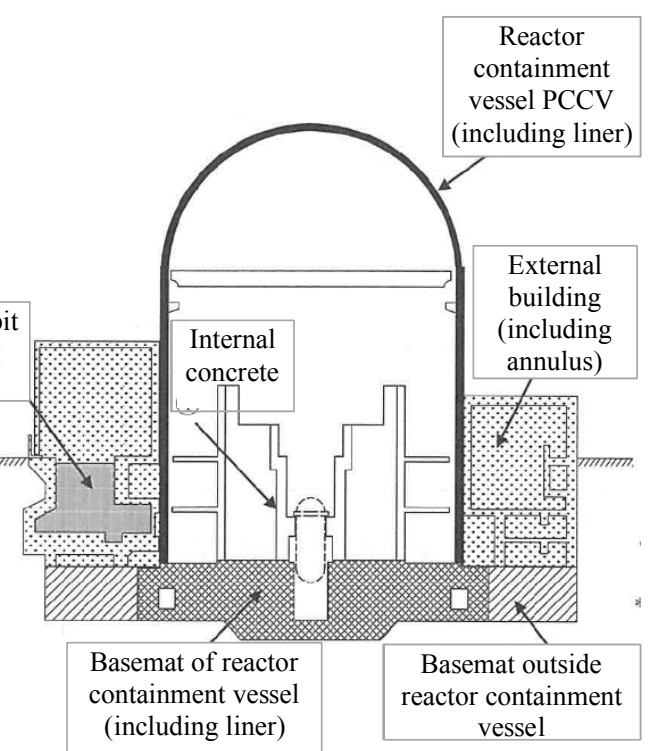

Fig. 1 Concrete structures subject to nuclear power plant aging evaluations [revised versions of figures in AIJ Guidelines for Maintenance (AIJ 2015)]. 
There is a wide range of aggregates that can stably satisfy the dry unit weight and are produced close to the power plant. The type of aggregate can be confirmed at 13 power plants (Fig. 3). At one of these power plants, a different aggregate was used according to the time of year of the construction, and therefore 14 power plants are used in the statistics. "Natural" gravel that does not need crushing was used at five power plants, which were in an environment where "natural" sand can also be procured for the fine aggregate. Of the nine power plants

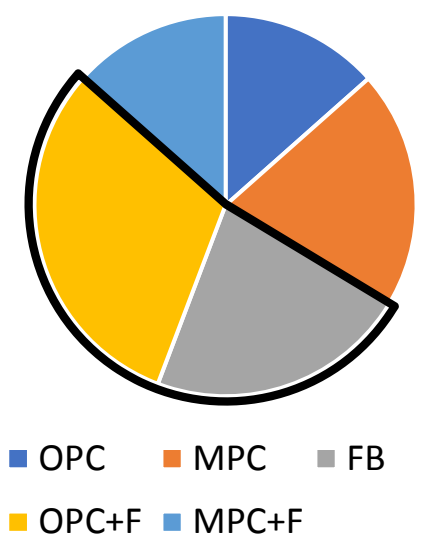

Fig. 2 Frequency of cement used.

natural gravel with natural sand

crushed stone with natural sand*

crushed stone with natural and crushed sand

crushed stone with crushed sand

*Includes mixtures of sand produced in different regions.

Fig. 3 Aggregate procurement. that used crushed stone as a coarse aggregate, three power plants used natural sand as a fine aggregate and six power plants used crushed sand, including those that used crushed sand mixed with natural sand. Of these, one power plant used a combination of crushed stone and sand.

Regarding the concrete specifications, Figs. 4 through 7 show the water-cement ratio, unit cement content, slump, and design strength. The specifications shown are divided into those for the fly ash cement and the equivalent binder, which were used in approximately half of the 104 mixes surveyed, and those for the other cements. Mixtures with a water-binder ratio of greater than $47 \%$ and less than or equal to $50 \%$ were most common in both cases. A unit cement content of greater than 300 $\mathrm{kg} / \mathrm{m}^{3}$ and less than or equal to $320 \mathrm{~kg} / \mathrm{m}^{3}$ was most common for fly ash cement type $\mathrm{B}$ and the equivalent binder, whereas a unit cement content of greater than 320 $\mathrm{kg} / \mathrm{m}^{3}$ and less than or equal to $340 \mathrm{~kg} / \mathrm{m}^{3}$ was most common for the other binders. A slump of greater than 8 $\mathrm{cm}$ and less than or equal to $12 \mathrm{~cm}$ was most common in both binder categories. In addition, there were eight mixtures that underwent fluidization treatment with the addition of a fluidizer at the construction location and thus the slump was between 12 and $18 \mathrm{~cm}$. Approximately half $(54 \%)$ of the mixtures had a design strength
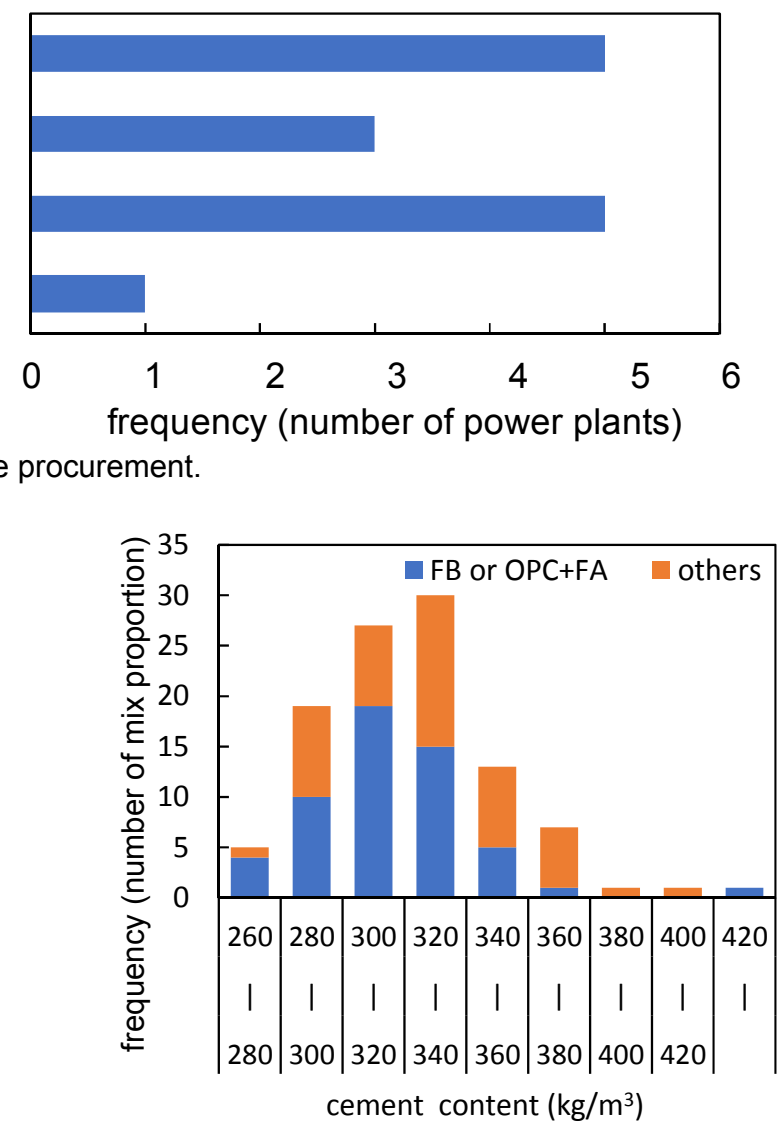

Each interval is greater than the smaller value and less than or equal to the larger value.

Fig. 4 Water-cement ratio [W/C or W/(C+FA)].

Each interval is greater than the smaller value and less than or equal to the larger value.

Fig. 5 Unit cement content. 
Table 1 Mix specification.

\begin{tabular}{l|l|l}
\hline \multicolumn{2}{c}{ Item } & \multicolumn{1}{c}{ Specification } \\
\hline \multirow{3}{*}{ Binder } & Cement: C & Ordinary Portland cement \\
\cline { 2 - 3 } & Admixture & Fly ash: FA \\
\cline { 2 - 3 } & Admixture replacement ratio: $\mathrm{FA} /(\mathrm{C}+\mathrm{FA})$ & $20 \%$ (equivalent to fly ash cement type B) \\
\hline Water-binder ratio: $\mathrm{W} /(\mathrm{C}+\mathrm{FA})$ & $50 \%$ \\
\hline Unit binder content: $\mathrm{C}+\mathrm{FA}$ & $310 \mathrm{~kg} / \mathrm{m}^{3}$ \\
\hline Slump & $12.0 \pm 2.5 \mathrm{~cm}$ \\
\hline Air content & $4.5 \pm 1.0 \%$ \\
\hline Design strength & $24 \mathrm{~N} / \mathrm{mm}^{2}$ \\
\hline
\end{tabular}

Table 2 Materials used.

\begin{tabular}{l|l}
\hline \multicolumn{1}{c|}{ Material } & \multicolumn{1}{c}{ Specification } \\
\hline Water & Tap water \\
\hline Cement & Ordinary Portland cement, Taiheiyo Cement Corporation \\
\hline Fly ash & Type II, Techno Chubu Co., Ltd. Hekinan Office, product of Hekinan Thermal Power Station \\
\hline \multirow{2}{*}{ Fine aggregate } & $\begin{array}{l}\text { Oi River system land sand, grain size of 0 to } 5 \mathrm{~mm} \text {, surface-dry density of } 2.59 \mathrm{~g} / \mathrm{cm}^{3}, \text { water absorp- } \\
\text { tion rate of } 1.92 \%, \text { solid content of } 67.8 \%\end{array}$ \\
\hline \multirow{2}{*}{ Coarse aggregate } & $\begin{array}{l}\text { Ome crushed stone, grain size of } 5 \text { to } 20 \mathrm{~mm}, \text { surface-dry density of } 2.66 \mathrm{~g} / \mathrm{cm}^{3}, \text { water absorption rate } \\
\text { of } 0.53 \%, \text { solid content of } 62.7 \%\end{array}$ \\
\hline \multirow{2}{*}{ Chemical admixtures } & AE water reducing agent, standard type (I), MasterPozzolith No. 70 (BASF Japan Ltd.) \\
\cline { 2 - 2 } & AE agent, Type I, MasterAir No. 785 (BASF Japan Ltd.) \\
\hline
\end{tabular}

Table 3 Concrete mix used $\left(\mathrm{kg} / \mathrm{m}^{3}\right)$.

\begin{tabular}{c|c|c|c|c|c|c}
\hline $\begin{array}{c}\text { Water } \\
\text { W }\end{array}$ & $\begin{array}{c}\text { Cement } \\
\text { C }\end{array}$ & $\begin{array}{c}\text { Fly ash } \\
\text { FA }\end{array}$ & $\begin{array}{c}\text { Fine aggregate } \\
\text { S }\end{array}$ & $\begin{array}{c}\text { Coarse aggregate } \\
\text { G }\end{array}$ & $\begin{array}{c}\text { AE water } \\
\text { reducing agent }\end{array}$ & $\begin{array}{c}\text { AE } \\
\text { agent }\end{array}$ \\
\hline 155 & 248 & 62 & 774 & 1055 & $\begin{array}{c}0.775 \\
(\mathrm{C}+\mathrm{FA}) \times 0.25 \%\end{array}$ & $\begin{array}{c}0.124 \\
(\mathrm{C}+\mathrm{FA}) \times 0.040 \%\end{array}$ \\
\hline
\end{tabular}

*Fine aggregate ratio of $44.0 \%$, maximum grain size of coarse aggregate of $20 \mathrm{~mm}$.

of greater than $22 \mathrm{~N} / \mathrm{mm}^{2}$ and less than or equal to 25 $\mathrm{N} / \mathrm{mm}^{2}$.

The mixture specification used in this study, which is shown in Table 1, is the typical and most common example of the concrete used in nuclear power plants in Japan, as found from the survey results. The specimens were cast with a single typical mixture of $20 \%$ fly ash and $50 \%$ water-binder ratio.

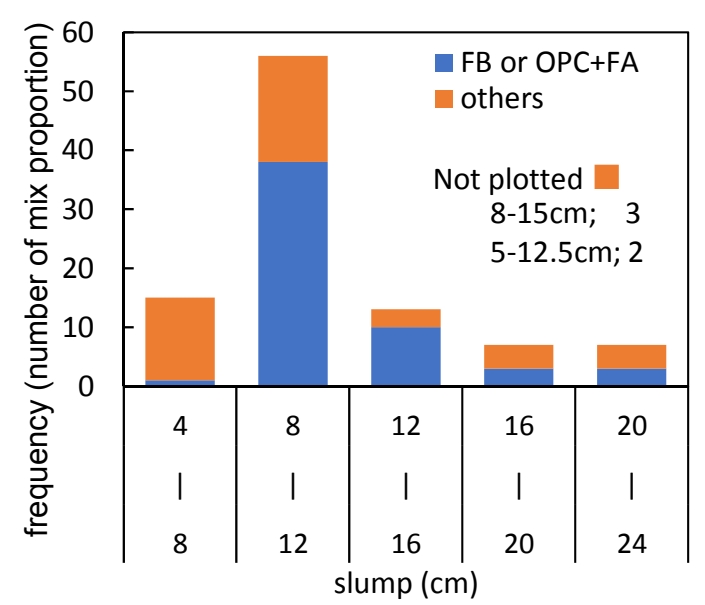

Each interval is greater than the smaller value and less than or equal to the larger value.

Fig. 6 Slump.

\section{Test for accelerated carbonation and rebar corrosion}

\subsection{Test method}

\subsubsection{Specimen production}

The specimens were produced using concrete satisfying the mixture specifications shown in Table 1. Table 2 shows the materials used. Trial mixes were prepared, and the mixture shown in Table 3 was chosen. The concrete

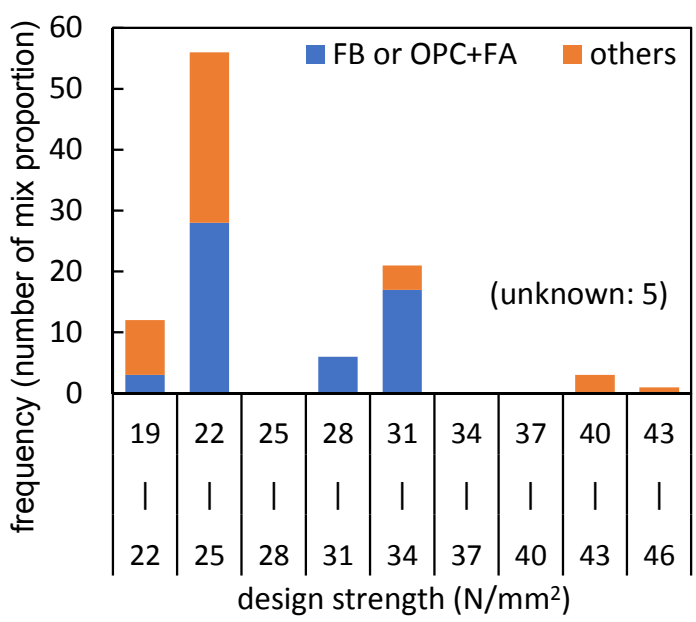

Each interval is greater than the smaller value and less than or equal to the larger value.

Fig. 7 Design strength. 
was produced in 12 batches. Figure 8 shows the fresh properties of the concrete. After confirming that both the slump and air content specifications shown in Table 1 were met, a rectangular specimen measuring $10 \times 10 \times 40$ $\mathrm{cm}$ (unreinforced specimen) and a rectangular specimen measuring $10 \times 10 \times 40 \mathrm{~cm}$ with a D13 rebars positioned with $3 \mathrm{~cm}$ of cover (reinforced specimen shown in Fig. 9, specimen cross-section shown in Fig. 10) were produced. The specimens were demolded the day after pouring and cured up to 28 days of age in water at $20^{\circ} \mathrm{C}$. Then, taking

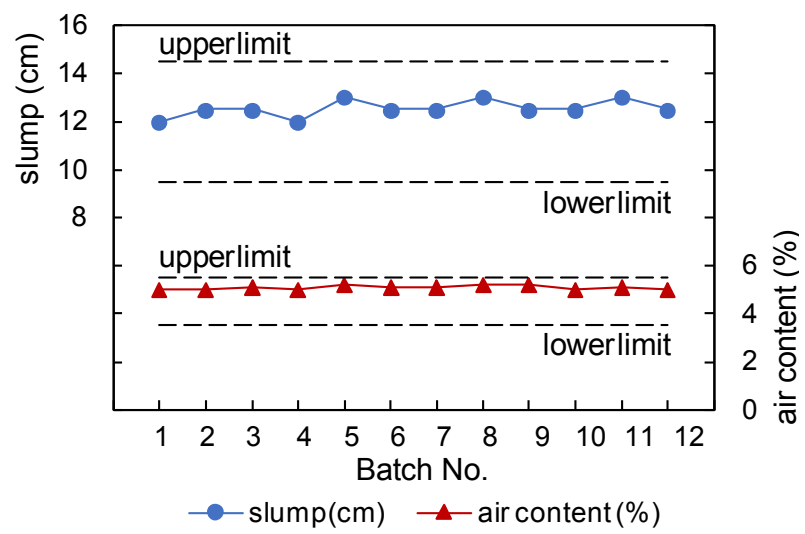

Fig. 8 Fresh properties of concrete used. exposure to the atmosphere at the site into account, the specimens were cured until 56 days of age at a temperature of $20^{\circ} \mathrm{C}$ and humidity of $60 \%$ (AIJ 1988, 2001). Figure 11 shows the strength of the concrete after these curing processes. After curing, one side surface measuring $10 \times 40 \mathrm{~cm}$ was taken as the exposed surface, and the other surfaces were coated with aluminum tape.

\subsubsection{Accelerated carbonation test and rebar cor- rosion test}

An accelerated carbonation test was conducted using the unreinforced and reinforced specimens. As described in Section 2.1, the upper limit of the temperature conditions to be examined was taken to be $65^{\circ} \mathrm{C}$ according to the provisions of the "Recommendations for Structural Design of Reactor Buildings (AIJ 1988)," but the temperature in the accelerated carbonation test was taken as $60^{\circ} \mathrm{C}$ in consideration of the capability of the test equipment to adjust to the humidity. The relative humidity was taken as $30 \%, 50 \%, 70 \%, 90 \%$, and $100 \%$. The test was conducted in an environment with a relative humidity of between $30 \%$ and $70 \%$ and with the $\mathrm{CO}_{2}$ concentration set at 5\%. Table 4 shows the curing conditions and duration of the specimens.

The carbonation depth and rebar corrosion were

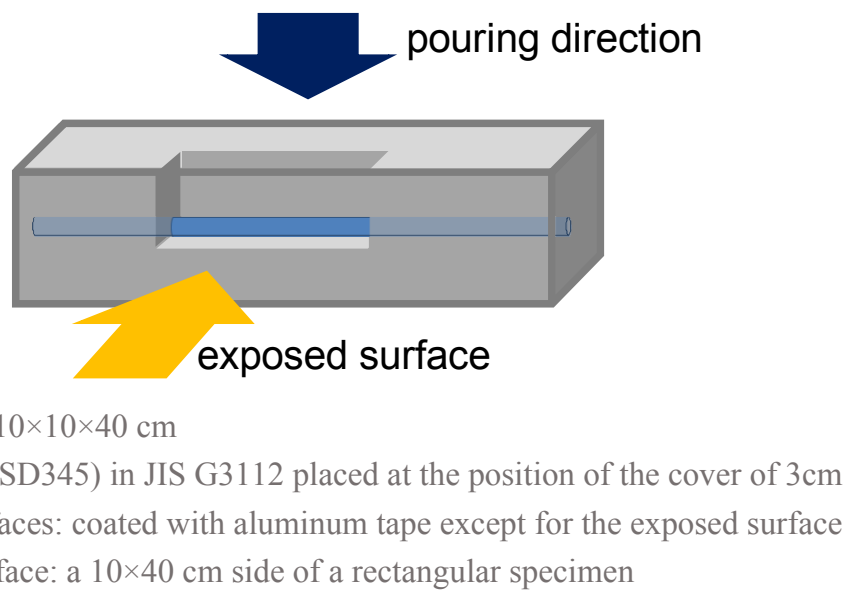

*dimension: $10 \times 10 \times 40 \mathrm{~cm}$

*rebar: D13 (SD345) in JIS G3112 placed at the position of the cover of $3 \mathrm{~cm}$

*surfaces: coated with aluminum tape except for the exposed surface

*exposed surface: a 10×40 cm side of a rectangular specimen

Fig. 9 Schematic drawing of specimen with rebar installed.

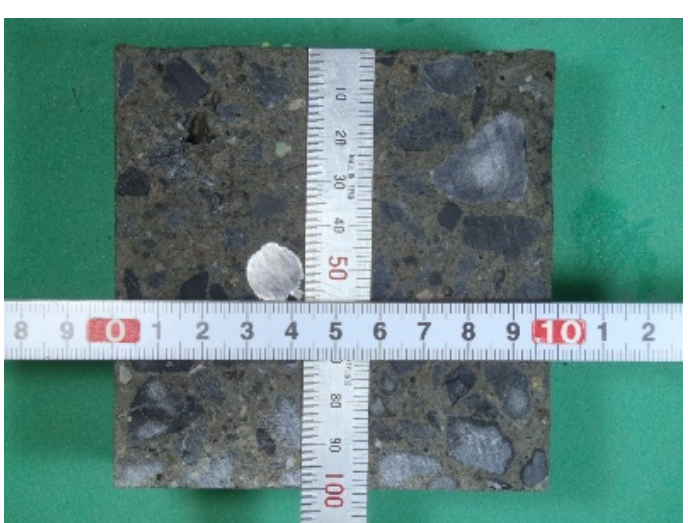

Fig. 10 Cross-section of produced specimen.

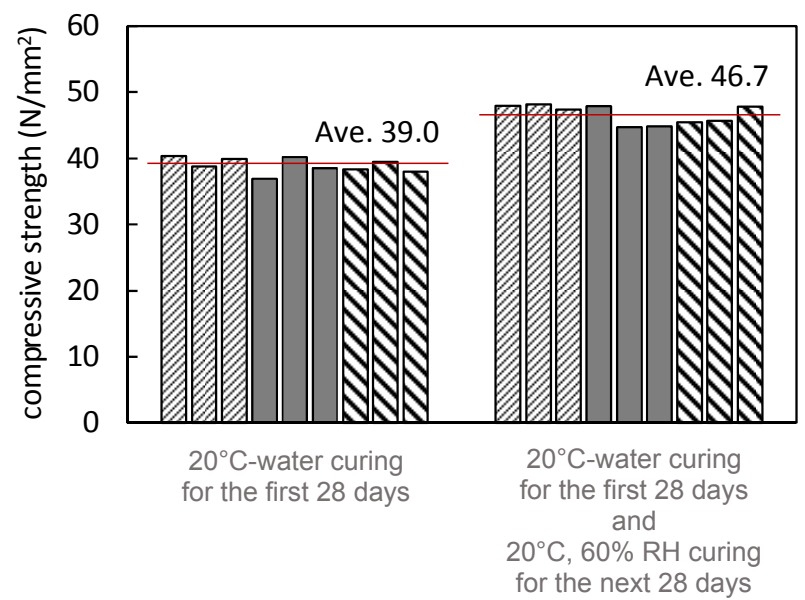

Fig. 11 Strength of concrete used. 
Table 4 Specimens and their RH conditions.

(a) Mass during adjustment curing.

\begin{tabular}{c|c|c|c|c|c}
\hline \multicolumn{2}{c|}{ Initial Curing $\left(20^{\circ} \mathrm{C}\right)$} & \multicolumn{2}{|c|}{ Adjustment Curing $\left(20^{\circ} \mathrm{C}\right)$} & \multirow{2}{*}{ Rebar } & Number of specimens tested \\
\cline { 3 - 4 } in water & $60 \% \mathrm{RH}$ ambt. $\mathrm{CO}_{2}$ & $\mathrm{RH}$ & Period & & Mass \\
\hline \multirow{3}{*}{$28 \mathrm{~d}$} & \multirow{3}{*}{$+28 \mathrm{~d}$} & $30 \%$ & $+91 \mathrm{~d}$ & No Rebar & 2 \\
\cline { 3 - 5 } & & $50 \%$ & $+91 \mathrm{~d}$ & No Rebar & 2 \\
\cline { 3 - 5 } & & $70 \%$ & $+91 \mathrm{~d}$ & No Rebar & 2 \\
\hline
\end{tabular}

(b) $30 \%, 50 \%$, and $70 \% \mathrm{RH}$ for corrosion.

\begin{tabular}{|c|c|c|c|c|c|c|c|c|c|}
\hline \multirow{2}{*}{$\begin{array}{l}\text { RH for } \\
\text { Corrosion }\end{array}$} & \multicolumn{2}{|c|}{$\begin{array}{l}\text { Initial Curing } \\
\left(20^{\circ} \mathrm{C}\right)\end{array}$} & \multicolumn{2}{|c|}{$\begin{array}{c}\text { Adjustment } \\
\text { Curing }\left(20^{\circ} \mathrm{C}\right)\end{array}$} & \multicolumn{2}{|r|}{$\begin{array}{l}\text { Accelerated Carbonation } \\
\left(60^{\circ} \mathrm{C}, 5 \% \mathrm{CO}_{2}\right)\end{array}$} & \multirow{2}{*}{ Rebar } & \multicolumn{2}{|c|}{ Number of specimens tested } \\
\hline & in water & $\begin{array}{c}60 \% \mathrm{RH} \\
\text { ambt. } \mathrm{CO}_{2}\end{array}$ & RH & Period & $\mathrm{RH}$ & Period $(*)$ & & $\begin{array}{c}\text { Carbonation } \\
\text { Depth }\end{array}$ & $\begin{array}{c}\text { Corrosion } \\
\text { Amount }\end{array}$ \\
\hline \multirow{7}{*}{$30 \%$} & \multirow{21}{*}{$28 \mathrm{~d}$} & \multirow{21}{*}{$+28 \mathrm{~d}$} & \multirow{7}{*}{$30 \%$} & \multirow{3}{*}{$+56 \mathrm{~d}$} & \multirow{3}{*}{$30 \%$} & $+7,28,56,91,182 \mathrm{~d}$ & \multirow{2}{*}{ No Rebar } & 3 & -- \\
\hline & & & & & & $+273,364,455 \mathrm{~d}, 2.3 \mathrm{y}$ & & 2 & -- \\
\hline & & & & & & $+91,182,273,364,455 \mathrm{~d}, 2.3 \mathrm{y}$ & Placed & see note & 1 for each Period $(*)$ \\
\hline & & & & \multirow{4}{*}{$+91 \mathrm{~d}$} & \multirow{4}{*}{$30 \%$} & $+7,28,56,91,182 \mathrm{~d}$ & \multirow{2}{*}{ No Rebar } & 3 & -- \\
\hline & & & & & & $+364,455 \mathrm{~d}$ & & 2 & -- \\
\hline & & & & & & $+91,273,364,455 \mathrm{~d}$ & \multirow{2}{*}{ Placed } & \multirow{2}{*}{ see note } & 1 for each Period $(*)$ \\
\hline & & & & & & $+2.3,3.8 \mathrm{y}$ & & & 2 for each Period $(*)$ \\
\hline \multirow{7}{*}{$50 \%$} & & & \multirow{7}{*}{$50 \%$} & \multirow{3}{*}{$+56 \mathrm{~d}$} & \multirow{3}{*}{$50 \%$} & $+7,28,56,91,182 \mathrm{~d}$ & \multirow{2}{*}{ No Rebar } & 3 & -- \\
\hline & & & & & & $+273,364,455 \mathrm{~d}, 2.3 \mathrm{y}$ & & 2 & -- \\
\hline & & & & & & $+91,182,273,364,455 \mathrm{~d}, 2.3 \mathrm{y}$ & Placed & see note & 1 for each Period $(*)$ \\
\hline & & & & \multirow{4}{*}{$+91 \mathrm{~d}$} & \multirow{4}{*}{$50 \%$} & $+7,28,56,91,273 \mathrm{~d}$ & \multirow{2}{*}{ No Rebar } & 3 & -- \\
\hline & & & & & & $+364,455 \mathrm{~d}$ & & 2 & -- \\
\hline & & & & & & $+91,273,364,455 \mathrm{~d}$ & \multirow{2}{*}{ Placed } & \multirow{2}{*}{ see note } & 1 for each Period $(*)$ \\
\hline & & & & & & $+2.3,3.8 \mathrm{y}$ & & & 2 for each Period $(*)$ \\
\hline \multirow{7}{*}{$70 \%$} & & & \multirow{7}{*}{$70 \%$} & \multirow{3}{*}{$+56 \mathrm{~d}$} & \multirow{3}{*}{$70 \%$} & $+7,28,56,91,182 \mathrm{~d}$ & \multirow{2}{*}{ No Rebar } & 3 & -- \\
\hline & & & & & & $+273,364,455 \mathrm{~d}, 2.3 \mathrm{y}$ & & 2 & -- \\
\hline & & & & & & $+91,182,273,364,455 \mathrm{~d}, 2.3 \mathrm{y}$ & Placed & see note & 1 for each Period $(*)$ \\
\hline & & & & & & $+7,28,56,91,273 \mathrm{~d}$ & No Rehar & 3 & -- \\
\hline & & & & $+01 d$ & $70 \%$ & $+364,455 \mathrm{~d}$ & No Kebar & 2 & -- \\
\hline & & & & +910 & $10 \%$ & $+91,273,364,455 \mathrm{~d}$ & Placed & & 1 for each Period $(*)$ \\
\hline & & & & & & $+2.3,3.8 \mathrm{y}$ & Praced & me & 2 for each Period $(*)$ \\
\hline
\end{tabular}

note: Carbonation depth for rebar-placed specimens was measured only to check that it is deeper than rebar.

*: Corrosion was measured on one or two rebar-placed specimens for each accelerated carbonation period.

**: Mass during the adjustment curing was measured for the specimens.

(c) $90 \%$ and $100 \%$ RH for corrosion.

\begin{tabular}{|c|c|c|c|c|c|c|c|c|c|c|c|}
\hline \multirow{2}{*}{$\begin{array}{c}\mathrm{RH} \text { for } \\
\text { Corrosion }\end{array}$} & \multicolumn{2}{|c|}{$\begin{array}{l}\text { Initial Curing } \\
\quad\left(20^{\circ} \mathrm{C}\right)\end{array}$} & \multicolumn{2}{|c|}{$\begin{array}{c}\text { Adjustment } \\
\text { Curing }\left(20^{\circ} \mathrm{C}\right)\end{array}$} & \multicolumn{2}{|c|}{$\begin{array}{c}\text { Accelerated } \\
\text { Carbonation } \\
\left(60^{\circ} \mathrm{C}, 5 \% \mathrm{CO}_{2}\right)\end{array}$} & \multicolumn{2}{|c|}{$\begin{array}{l}\text { Curing in High Humidity } \\
\left(60^{\circ} \mathrm{C}, \text { Ambient } \mathrm{CO}_{2}\right)\end{array}$} & \multirow[t]{2}{*}{ Rebar } & \multicolumn{2}{|c|}{ Number of specimens tested } \\
\hline & in water & $\begin{array}{l}60 \% \mathrm{RH} \\
\text { ambt. } \mathrm{CO}_{2}\end{array}$ & $\mathrm{RH}$ & Period & RH & Period & RH & Period $(*)$ & & \begin{tabular}{|c|} 
Carbonation \\
Depth
\end{tabular} & $\begin{array}{l}\text { Corrosion } \\
\text { Amount }\end{array}$ \\
\hline $90 \%$ & \multirow{2}{*}{$28 \mathrm{~d}$} & \multirow{2}{*}{$+28 \mathrm{~d}$} & $50 \%$ & $\begin{array}{l}+56 \mathrm{~d} \\
+91 \mathrm{~d}\end{array}$ & $50 \%$ & $+273 \mathrm{~d}$ & $90 \%$ & \begin{tabular}{|c|}
$+91 \mathrm{~d}, 182 \mathrm{~d}, 1.6 \mathrm{y}$ \\
$3.3 \mathrm{y}$
\end{tabular} & Placed & \multirow{2}{*}{ see note } & $\begin{array}{l}2 \text { for each Period }(*) \\
2 \text { for each Period }(*)\end{array}$ \\
\hline $100 \%$ & & & $50 \%$ & $\begin{array}{l}+56 \mathrm{~d} \\
+916 \mathrm{~d}\end{array}$ & $50 \%$ & $+273 \mathrm{~d}$ & $100 \%$ & \begin{tabular}{|}
$+91 \mathrm{~d}, 182 \mathrm{~d}, 1.6 \mathrm{y}$ \\
$+2.4 \mathrm{y}, 2.9 \mathrm{y}, 3.5 \mathrm{y}$
\end{tabular} & Placed & & \begin{tabular}{|l|}
2 for each Period $(*)$ \\
1 for each Period $(*)$ \\
\end{tabular} \\
\hline
\end{tabular}

note: Carbonation depth for rebar-placed specimens was measured only to check that it is deeper than rebar.

evaluated as follows. The carbonation depth was determined from the uncolored area after spraying the specimen with phenolphthalein on the split surface perpendicular to the direction of the long axis of the specimen. Figure 12 shows an example of the carbonation depth measurement on the split surface. To test a specimen more than once, the split surface was covered with aluminum tape and the curing continued for the next test. The carbonation depth was measured at five points divided equally among six sections on the split surface. Specimens with rebars were split to remove the rebars.
The corrosion area ratio of the rebar taken from the specimen and the amount of corrosion were determined using a sketch of the rebar surface and the ammonium citrate dissolution method. The carbonation depth was also measured to determine whether the depth was deeper than that of the rebar. Figure 13 depicts an example of a rebar taken from specimen.

It was predicted based on past findings that the progression of carbonation will be slow in an environment with relative humidity of $90 \%$ and $100 \%$. Therefore, rebar corrosion was evaluated by allowing carbonation to 
progress at a temperature of $60^{\circ} \mathrm{C}$, relative humidity of $50 \%$, and $\mathrm{CO}_{2}$ concentration of $5 \%$, and then retaining the specimens in an environment with a temperature of $60^{\circ} \mathrm{C}$, humidity of $90 \%$ or $100 \%$, and $\mathrm{CO}_{2}$ concentration equal to the atmospheric concentration. The depth of carbonation that was allowed to progress in advance was set at "concrete cover $+2 \mathrm{~cm}$ or more" (carbonation depth of $5 \mathrm{~cm}$ or more), which is a rough indicator for the occurrence of rebar corrosion based on the "Guidelines for Maintenance" (AIJ 2015). As in the test at 30\% to $70 \%$ relative humidity, rebar corrosion was evaluated using a sketch of the rebar surface and an ammonium citrate dissolution method.

To align the humidity conditions of the accelerated carbonation test and the humidity environment inside the specimens, the specimens were left in a constant temperature and humidity chamber at a temperature of $60^{\circ} \mathrm{C}$ and a specific humidity environment $(30 \%, 50 \%, 70 \%)$ as "adjustment curing" prior to the accelerated carbonation test. Figure $\mathbf{1 4}$ shows a change in mass of the specimens without rebar during the adjustment curing. Little change in mass was seen at any of the humidity levels after 56 days or more had elapsed, and therefore, specimens that had undergone adjustment curing for 56 or 91 days were used in the accelerated carbonation test.

\subsection{Test results}

\subsubsection{Rate of progression of carbonation}

Figure 15 shows the state of progression of carbonation as a result of the accelerated carbonation test on the specimens without rebar at relative humidities between $30 \%$ and $70 \%$. The horizontal axis shows the square root of elapsed time during the test. Under all test conditions, the change in carbonation depth can be approximated as a straight line until the carbonation depth reaches approximately $70 \mathrm{~mm}$, and similar to past findings, the

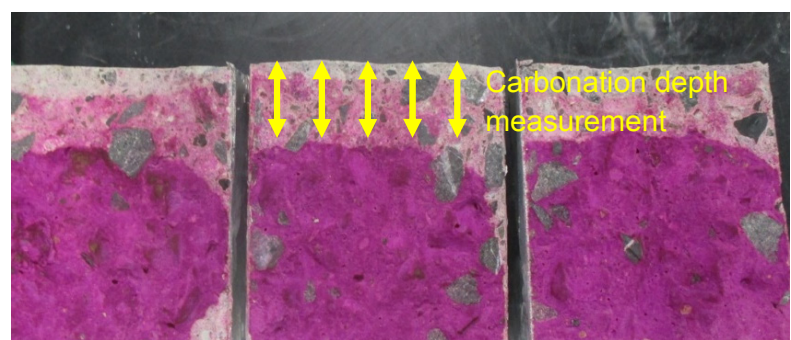

Fig. 12 Example of carbonation (56 days of adjustment curing, $30 \% \mathrm{RH}, 91$ days of accelerated carbonation).

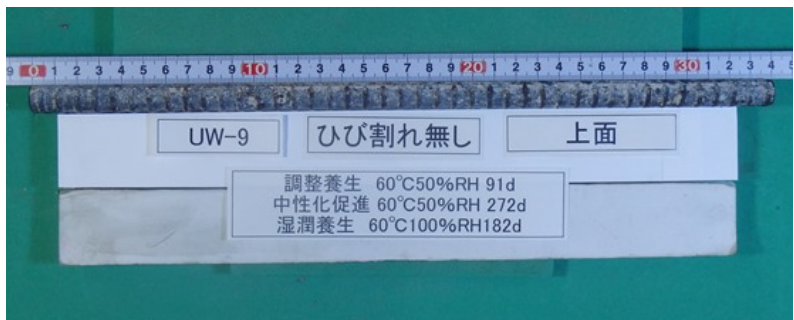

Fig. 13 Example of rebar taken from specimen (182 days of $100 \% \mathrm{RH})$. carbonation depth progressed in proportion to the square root of the elapsed time. In addition, even though the adjustment curing time differed (56 days and 91 days), the linear approximations showing a change in carbonation depth were similar under each of the humidity conditions, with no marked difference found. This is considered to be compatible with the fact that no difference was found in the change in mass shown in Fig. 14.

The constant of the proportionality when the progression of carbonation depth was taken to be proportional to the square root of the elapsed time was found as the accelerated carbonation rate coefficient. Figure 16 shows the determined accelerated carbonation rate coefficient along with the rate coefficient estimated using the AIJ durability design equation [Eq. (1)] given in the "Guidelines for Maintenance" (AIJ 2015) and half of that value.

$$
C=k \cdot \alpha_{1} \cdot \alpha_{2} \cdot \alpha_{3} \cdot \beta_{1} \cdot \beta_{2} \cdot \beta_{3} \cdot \sqrt{t}
$$

where,

$C$ is the carbonation depth $(\mathrm{cm})$;

$t$ is the time (years);

$K$ is a coefficient $(=1.72$, used as the improved Kishitani formula);

$\alpha_{1}$ is a coefficient depending on the type of concrete $(=$

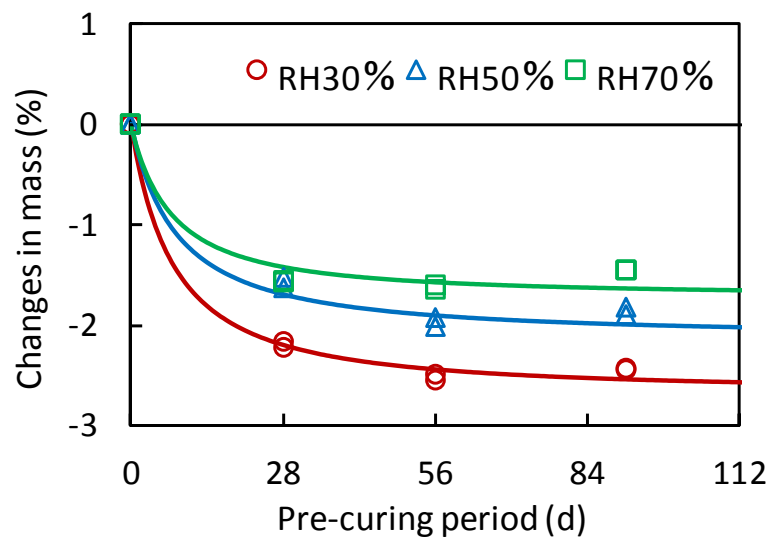

Fig. 14 Change in mass during adjustment curing.

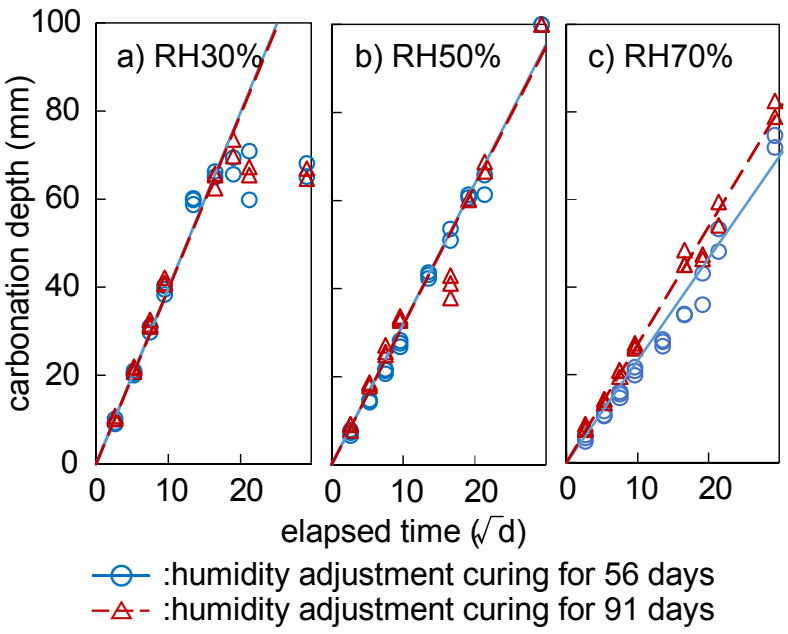

Fig. 15 Results of accelerated carbonation test. 
1.0 , ordinary concrete);

$\alpha_{2}$ is a coefficient depending on the type of cement $(=1.8$, fly ash cement type B);

$\alpha_{3}$ is a coefficient depending on the water-cement ratio $(=w / c-0.38)$, where $w / c$ is the water-cement ratio);

$\beta_{1}$ is a coefficient depending on temperature, given by, $\beta_{1}$ $=(0.017 \times T+0.48) / 0.75$, where $T$ is the temperature $\left({ }^{\circ} \mathrm{C}\right)$ and 0.75 is the coefficient for annual average temperature $\left(15.9^{\circ} \mathrm{C}\right)$ of the Tokyo area;

$\beta_{2}$ is a coefficient depending on humidity, given by, $[(H u \times(100-H u) \times(140-H u) / 192000] / 0.93$, where $H u$ is the relative humidity (\%) and 0.93 is the coefficient for annual average relative humidity $(63 \%)$ of the Tokyo area, and $\beta_{3}$ is a coefficient depending on $\mathrm{CO}_{2}$ concentration, given by, $\left[\sqrt{ }\left(\mathrm{CO}_{2} / 5.0\right) / 0.1\right]$, where $\mathrm{CO}_{2}$ is the carbon dioxide concentration $(0.20 \%$, indoors $)$ and 0.1 is the coefficient for outdoor carbon dioxide concentration $(0.05 \%)$.

The accelerated carbonation rate coefficient determined showed the same tendency with the durability design equation (AIJ equation). The test results conservatively agreed with half of the value of the equation. The test results showed that the carbonation rate coefficient for concrete made using the ingredients and/or mixtures frequently used at nuclear power plants in a high temperature $\left(60^{\circ} \mathrm{C}\right)$ environment, under which carbonation is considered to progress quickly, can be predicted over a wide range of humidity, with an approximately two-fold margin, using the AIJ equation. The test results confirmed that, even if sampling is not used, a conservative (safe) diagnosis and prediction are possible using the AIJ equation, as long as the ambient temperature and humidity environment can be determined.

\subsubsection{Rebar corrosion rate}

The rebar was removed from the specimens that had undergone the accelerated carbonation test in a relative humidity environment of $30 \%$ to $70 \%$ at a given age, and the corrosion area and corrosion amount were measured. The corrosion area was measured by wrapping a transparent resin film around the rebar and transcribing the scope of the corrosion, and then measuring the area of the transcribed corrosion scope using a planimeter. The corroded portion was dissolved using the ammonium citrate dissolution method, and the mass of the corroded rebar was found by subtracting the mass of the rebar after corrosion from the mass of the rebar measured before the specimens were made.

For the test conditions of $90 \%$ to $100 \%$ relative humidity, carbonation was accelerated under an environment with a temperature of $60{ }^{\circ} \mathrm{C}, 50 \%$ relative humidity, and $\mathrm{CO}_{2}$ concentration of $5 \%$, and after confirming that carbonation had progressed to $5 \mathrm{~cm}$ or more using the accelerated carbonation rate coefficient shown in Fig. 16, the specimens were transferred to a relative humidity environment of $90 \%$ or $100 \%$ as shown in Table 4 . The specimens were transferred when the carbonation depth was $5 \mathrm{~cm}$ because the "Guidelines for Maintenance" (AIJ 2015) take the progression of carbonation to "concrete cover $+2 \mathrm{~cm}$ " as a rough indicator for the occurrence of rebar corrosion. Rebar corrosion in specimens that had reached a given age in a relative humidity environment of $90 \%$ or $100 \%$ was measured in the same way as for the specimens in a relative humidity environment of $30 \%$ to $70 \%$.

Figure 17 shows the corrosion area ratio of the rebar. The horizontal axis was converted into the elapsed time from the age at which the carbonation depth reached 5 $\mathrm{cm}$, which is a rough indicator for the occurrence of rebar corrosion owing to carbonation. The measured value of the accelerated carbonation rate coefficient shown in Fig. 16 was used in the conversion. In the case of $90 \%$ and $100 \%$ humidity, this is the elapsed time after the specimens were transferred to the given humidity environment. When the humidity was $100 \%$, corrosion started early, and after approximately 3 years almost the entire surface was corroded. In the case of $90 \%$ humidity, where the corrosion area ratio reached approximately $70 \%$, the curve of the same shape with the curve for $100 \% \mathrm{RH}$ is demonstrated in the figure. Although corrosion of $90 \%$ HR appeared to start approximately 1.6 years later than in the case of $100 \%$ humidity, the results suggest the

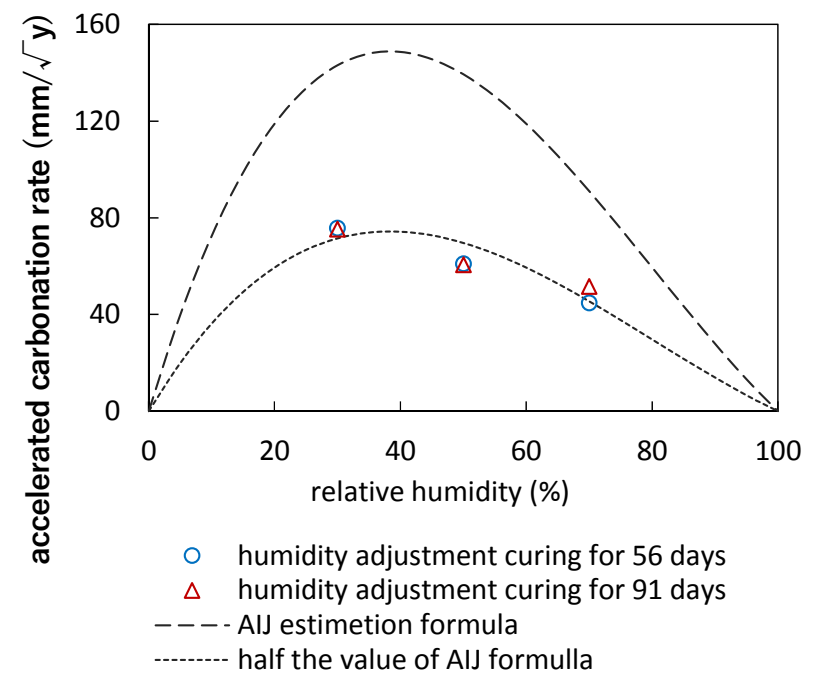

Fig. 16 Accelerated carbonation rate coefficient at $60^{\circ} \mathrm{C}$.

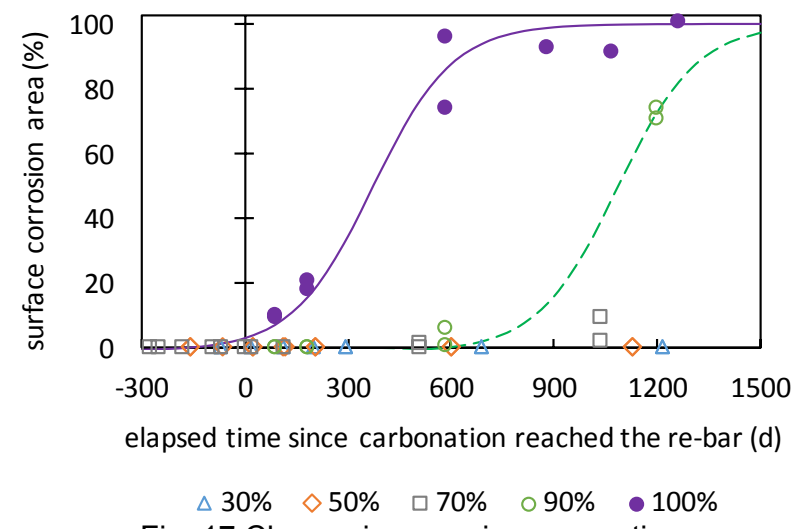

Fig. 17 Change in corrosion area ratio. 


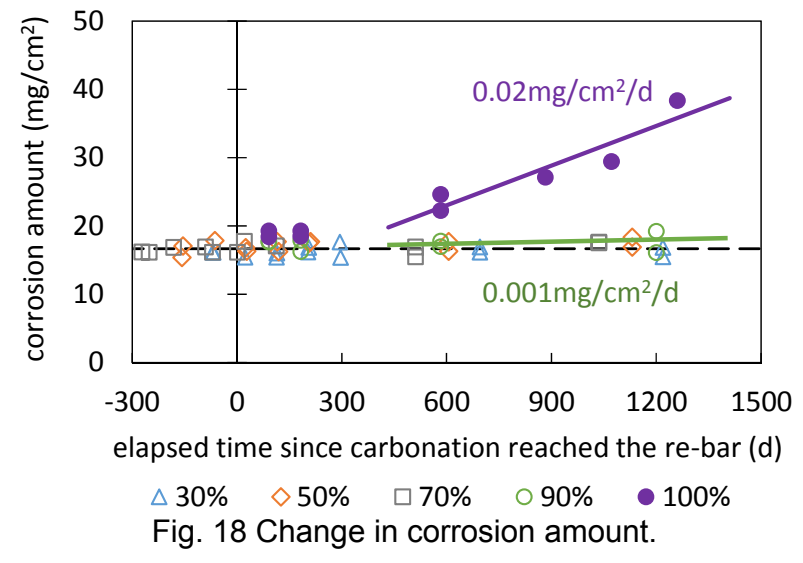

possibility that the period from the start of corrosion until it had spread over the entire surface is the same even if the humidity conditions differ. The curve for $70 \% \mathrm{RH}$ is not demonstrated because it only shows small signs of corrosion on the rebar surface but not following progression. In the case of $30 \%$ and $50 \%$ relative humidity, corrosion was not found, even after approximately 3 years after the carbonation depth reached the rough indicator for the occurrence of $5 \mathrm{~cm}$ of rebar corrosion.

The change in the amount of rebar corrosion was found using the ammonium citrate dissolution method and was divided by the nominal surface area to give the corrosion amount per unit of surface area, as shown in Fig. 18. Because "red rust" from carbonation and "black rust," which is a coating, are dissolved using this dissolution method, even when the corrosion area ratio was $0 \%$, approximately $16.7 \mathrm{mg} / \mathrm{cm}^{2}$ of corrosion (dashed line in the figure) was observed owing to the dissolution of black rust. In the case of $100 \%$ humidity, the corrosion area ratio after 1260 days was $100 \%$; however, the amount of corrosion was small, being equivalent to only $0.8 \%$ of the total mass (approximately $2488 \mathrm{mg} / \mathrm{cm}^{2}$ ). In addition, the corrosion rate after corrosion had spread over almost the entire surface was found from the corrosion amount to be approximately $0.02 \mathrm{mg} / \mathrm{cm}^{2} / \mathrm{d}$. In the case of $90 \%$ humidity, the amount of corrosion was small, and it is irrelevant to discuss the amount of corrosion or determine the corrosion rate. However, for reference, the corrosion rate up to a corrosion area ratio of approximately $70 \%$ was found to be approximately 0.001 $\mathrm{mg} / \mathrm{cm}^{2} / \mathrm{d}$, which is $1 / 20$ th of that in the case of $100 \%$ humidity. This suggests that when the humidity environment is lowered from the $100 \%$ condition aimed at confirming the corrosion behavior to approximately the $70 \%$ level that is assumed in reality, the corrosion rate becomes extremely low.

\subsection{Progression of carbonation and rebar cor- rosion}

The following findings were obtained from the accelerated carbonation test at $60^{\circ} \mathrm{C}$, using the rebar corrosion behavior at $100 \%$ humidity as a reference.

1) Even when sampling is impossible, it is possible to diagnose and predict the carbonation using the pre- diction equation given in the "Guidelines for Maintenance" (AIJ 2015).

2) Even if carbonation progresses as far as the rough indicator for the occurrence of carbonation (concrete cover $+2 \mathrm{~cm}$ ), if the relative humidity is approximately $90 \%$ or lower, the rebar will not corrode for at least several years.

3) If the relative humidity is $90 \%$ or lower, the rate of rebar corrosion may be much lower than when the relative humidity is $100 \%$.

4) The predicted coefficient of the carbonation rate is highest at $40 \%$ humidity and is almost zero at $100 \%$. In contrast, the rebar corrosion rate is high at $100 \%$ humidity and is considered to be low at a humidity less than $100 \%$. Accordingly, provided that they are not subjected to extreme dry-wet cycles at humidity levels of 100 to $40 \%$, concrete structures in high-temperature environments ranging from room temperature to $60^{\circ} \mathrm{C}$ are unlikely to degrade through carbonation-induced rebar corrosion.

\section{Discussion}

Maintenance of concrete structures at nuclear power plants in Japan is conducted in accordance with the guidelines of the Architectural Institute of Japan, and carbonation is one of the degradation factors covered by the guidelines. Electricity providers in Japan perform sampling at locations constituting environments (temperature, relative humidity, carbon dioxide concentration) where carbonation progresses relatively fast to measure the depth of carbonation and to predict progression. There are few data on the parameter of relative humidity in relation to carbonation and the resulting rebar corrosion in high temperature environments, where carbonation is believed to progress fast. To make sample-testing-based evaluations more representative, tests were conducted with the objective of obtaining data to facilitate evaluation without the need for sampling in high temperature environments. Rebars were removed from the specimen and detailed corrosion measurements were performed.

Concrete structures in Japanese nuclear power plants must be designed to always remain below $65^{\circ} \mathrm{C}$, according to the Nuclear Reactor Building Structural Design Guidelines. Under this consideration in high-temperature environments, we obtained data that facilitate the evaluation of the progression of carbonation and rebar corrosion with humidity as a parameter.

As Leemann et al. (2016) reported, carbonation resistance varies depending on the concrete mix and there exists a range of the relative humidity in which the carbonation rate is the highest. For a typical concrete mix in nuclear power plants in Japan, the depth of carbonation could be predicted well in advance using the AIJ equation.

The results of direct measurements of the corrosion area and corrosion amount on the rebars removed from 
the specimen indicated that the corrosion amount was low even when the entire surface had corroded. This is consistent with the report by Stefanonia et al. (2018). Subsequently, it was determined that corrosion progresses gradually in the depth direction, increasing the corrosion amount. In past studies, the amount of corrosion was often estimated using electrochemical methods; however, in the present study, it was measured directly. It is believed that the development of cracks in the concrete cover and its impact on structural performance occurs after a certain amount of progression of corrosion in the depth direction.

Because the humidity at which carbonation progresses and that at which rebar corrosion progresses differ, it is unlikely that reinforced concrete degrades due to carbonation-induced rebar corrosion, even in a high-temperature environment where carbonation progresses (environments subject to extreme wet-dry cycles excluded).

It is anticipated that in nuclear power plants with an indoor environment of high $\mathrm{CO}_{2}$ concentrations and a high-temperature environment where the carbonation rates are high, an environment with extreme wet-dry cycles of humidity fluctuations is highly unlikely to occur. For such cases, a method to evaluate rebar corrosion based on the ratio of high humidity periods is proposed by Yonezawa et al. (2014).

\section{Conclusions}

1) To increase the representative nature of sample-testing-based evaluations, we conducted tests with the objective of obtaining data to facilitate evaluations without the need for sampling in high-temperature environments. Tests were conducted from the perspective of the impact of relative humidity on carbonation and carbonation-induced rebar corrosion and the results were analyzed. Design conditions for normal operation in the Nuclear Reactor Building Structural Design Guidelines state that temperatures must not exceed $65^{\circ} \mathrm{C}$. Our tests were conducted with humidity as a parameter, in a high-temperature environment of $60^{\circ} \mathrm{C}$, where carbonation progression is fast.

2) The result indicated that for a typical concrete mix in nuclear power plants in Japan, the depth of carbonation could be predicted well in advance using the AIJ equation.

3) It was confirmed that the corrosion amount was low even when the entire surface had corroded and the corrosion amount subsequently increased gradually.

4) The humidity at which carbonation progresses and that at which rebar corrosion progresses differ. Thus, we demonstrated the feasibility of evaluating the carbonation and rebar corrosion based on environmental conditions (temperature, relative humidity, carbon dioxide concentration) without the need for sampling, even in high-temperature environments where carbonation progresses fast, provided that there are no extreme humidity cycles.

\section{Acknowledgments}

This study was carried out as part of collaborative research by Chubu Electric Power Co., Inc., Hokkaido Electric Power Co., Inc., Tohoku Electric Power Co., Inc., Tokyo Electric Power Company Holdings, Inc., Hokuriku Electric Power Co., Inc., Kansai Electric Power Co., Inc., Chugoku Electric Power Co., Inc., Shikoku Electric Power Co., Inc., Kyushu Electric Power Co., Inc., The Japan Atomic Power Company, Electric Power Development Co., Ltd. and Japan Nuclear Fuel Limited. We are grateful for the guidance we received from Professor Emeritus Katsuki Takiguchi, Tokyo Institute of Technology; Dr. Hideo Kasami; Professor Shigemitsu Hatanaka, Mie University; Professor Ichizo Kishimoto, Kindai University; and Professor Ippei Maruyama, Nagoya University.

\section{References}

Adachi, M., Kiyohara, K., Mitarai, Y. and Hiraoka, N., (1993). "Concrete for nuclear power plant facilities." Concrete Journal, 31(3), 61-66. (in Japanese)

AIJ, (1988). "Recommendations for structural design of reactor buildings." Tokyo: Architectural Institute of Japan. (in Japanese)

AIJ, (2001). "Reinforced concrete work at nuclear power plants (Japan Architectural Standard Specification JASS 5N)." Tokyo: Architectural Institute of Japan. (in Japanese)

AIJ, (2015). "Guidelines for maintenance and management of structures in nuclear facilities." Tokyo: Architectural Institute of Japan.

Ceukelaire, L. D. and Nieuwenburg, D. V., (1993). "Accelerated carbonation of a blast-furnace cement concrete." Cement and Concrete Research, 23, 442-452.

Chen, Y., Liu, P. and Yu, Z., (2018). "Effects of environmental factors on concrete carbonation depth and compressive strength." Materials, 11(11), 2167.

Drouet, E., Poyet, S., Bescop, P. L., Torrenti, J. M. and Bourbon, X., (2019). "Carbonation of hardened cement pastes: Influence of temperature." Cement and Concrete Research, 115, 445-459.

Ferreira, M., Bohner, E. and Saarela, O., (2015). "Modelling the time to concrete cover cracking due to reinforcement corrosion." In: Proceedings of the 23rd International Conference on Structural Mechanics in Reactor Technology, Manchester, UK 10-14 August 2015. New York: Curran Associates. Vol. 3, 1454-1463.

Ferreira, M., Bohner, E. and Saarela, O., (2016). "Designing concrete durability by coupling limit states of corrosion initiation and corrosion induced cracking of concrete cover." Nordic Concrete Research, 54, 7-20.

Fujino, T. and Kushida, T., (1969). "Concrete works at Tsuruga Nuclear Power Plant." Concrete Journal, 
17(9), 21-31. (in Japanese)

Fujiwara, K., (2008). “Tsuruga Nuclear Power Plant Unit 1.” Concrete Journal, 46(9), 147-150. (in Japanese)

Hayashi, T. and Fujiki, Y., (1972). "Execution of concrete in Shimane Nuclear Power Station shielding wall." Concrete Journal, 10(2), 23-32. (in Japanese)

Horiuchi, M., Sugihara, K. and Iwasawa, J., (1975). "Concrete works in the construction of Unit 1 at Hamaoka Nuclear Power Plant." Concrete Journal, 13(8), 11-20. (in Japanese)

Houst, Y. F., (1996). "The role of moisture in the carbonation of cementitious materials." Internationale Zeitschrift für Bauinstandsetzen, 2(1), 49-66.

Huet, B., L'Hostis, V., Idrissi, H. and Tovena, I., (2003). "A review on corrosion mechanisms of reinforced concrete degradation." In: Proceedings of the International Conference on Environmental Degradation of Engineering Materials (EDEM 2003), Bordeaux, France 29 June-July 2003. Leeds, UK: Maney Publishing.

Ibaraki, M., Sugawara, N., Hakozaki, T. and Sugita, H., (1995). "Consideration of concrete strength in new construction of Unit 2 of Onagawa Nuclear Power Plant." Proceedings of AIJ Tohoku Chapter Architectural Research Meeting, 58, 311-314. (in Japanese)

Inoue, K., Kai, S., Yamazaki, A., Takahashi, H., Nakane, J. and Kubota, S., (1974a). "Concrete quality management in nuclear power plant construction, Part 1: Concrete quality management standards." Summaries of Technical Papers of Annual Meeting of the Architectural Institute of Japan, 49, 147-148. (in Japanese)

Inoue, K., Kai, S., Yamazaki, A., Takahasi, H. and Kubota, S., (1974b). "Concrete quality management in nuclear power plant construction, Part 2: Concrete quality management results." Summaries of technical papers of annual meeting of Architectural Institute of Japan, 49, 149-150. (in Japanese)

Inoue, K., Shigenobu, M., Fukushima, K., Noguchi, H., Noda, Y. and Sakaguchi, T., (1989). "Precooling of concrete with flake ice - Manufacturing equipment of concrete in Genkai Unit No. 3/4 Nuclear Power Station - Construction." Cement \& Concrete, 505, 8-19. (in Japanese)

Ishii, T., (1982). "Concrete quality management in construction of Shikoku Electric Power Company's Ikata Nuclear Power Plant Unit 2." Cement \& Concrete, 421, 44-55. (in Japanese)

Kadoki, S., Yoshida, K. and Tagawa, M., (2003). "Concrete production by batching plant for Shika Nuclear Power Plant Unit 2 and quality management." Electric Power Civil Engineering, 306, 54-58. (in Japanese)

Kanamori, N., Yamamoto, M. and Kamio, A., (1983). "Concrete works in the construction of Unit No. 3 and No. 4 at Takahama Nuclear Power Station of the Kansai Electric Power Company." Concrete Journal,
21(11), 61-71. (in Japanese)

Kawahara, K., Yoshioka, Y. and Ito, Y., (2009). "Concrete production by concrete plant for Shimane Nuclear Power Plant Unit 3 and quality management." Electric Power Civil Engineering, 341, 57-61. (in Japanese)

Leemann, A. and Moro, F., (2016). "Carbonation of concrete - The role of $\mathrm{CO}_{2}$ concentration, relative humidity and $\mathrm{CO}_{2}$ buffer capacity." Materials and Structures, 50(1), 30-43.

Liu, P., Chen, Y., Yu, Z. and Zhang, R., (2019). "Effect of temperature on concrete carbonation performance." Advances in Materials Science and Engineering, Article ID 9204570.

Masaoka, I. and Saito, M., (1982). "Concrete works in the construction of the Fukushima No. 2 Nuclear Power Plant." Concrete Journal, 20(7), 32-41. (in Japanese)

Morishita, H., (1997). "Nuclear power plants." Concrete Journal, 35(3), 58-61. (in Japanese)

Morishita, H., Tsuchiya, Y., Eguchi, K. and Hosaka, H., (1998a). "Construction of Kashiwazaki-Kariwa Nuclear Power Plant: Concrete production results." Concrete Journal, 36(5), 22-26. (in Japanese)

Morishita, H., Tsuchiya, Y., Eguchi, K. and Hosaka, S., (1998b). "Construction of Kashiwazaki-Kariwa Nuclear Power Plant: Mix design and quality control of concrete for RCCV in Unit No. 6 and 7." Concrete Journal, 36(9), 39-42. (in Japanese)

Morishita, H., Tsuchiya, Y., Kaneko, S. and Nakamura, K., (1998c). "Construction of Kashiwazaki-Kariwa Nuclear Power Plant: Construction method and technical study of concrete for RCCV in Unit No. 6 and 7." Concrete Journal, 36(10), 36-40. (in Japanese)

Nakajima, H., Tada, H. and Kitada, T., (1989). "Concrete production and quality management for Ikata Nuclear Power Plant Unit No. 3." Electric Power Civil Engineering, 218, 105-116. (in Japanese)

Nomura, A., Tanaka, H. and Shirosaka, Y., (1974). "Construction report for Unit 3 of Fukushima Nuclear Power Plant." Concrete Journal, 12(6), 72-81. (in Japanese)

Ogawa, Y., Sakaguchi, H. and Ichihashi, T., (2003). "Quality assurance initiatives at Hamaoka Nuclear Power Plant: Construction of water intake tank for Hamaoka Nuclear Power Plant Unit 5." Concrete Journal, 41(11), 45-50. (in Japanese)

Ohno, T., Terada, J. and Kogaki, Z., (1974). "Construction report for Units 1, 2 of Takahama Nuclear Power Plant.” Concrete Journal, 12(6), 72-92. (in Japanese)

Otsuka, S., Ishikawa, K. and Toiyama, M., (2004). "Construction of reinforced concrete containment vessel (RCCV): Hamaoka Nuclear Power Station Unit 5." Concrete Journal, 42(3), 49-54. (in Japanese)

Parrott, L. J., (1991). "Carbonation, moisture and empty pores." Advances in Cement Research, 4(15), 111-118.

Russell, D., Basheer, P. A. M., Rankin, G. I. B. and Long, 
A. E., (2001). "Effect of relative humidity and air permeability on prediction of the rate of carbonation of concrete." Structures and Buildings, 146(3), 319-326.

Salvoldi, B. G., Beushausen, H. and Alexander, M. G., (2015). "Oxygen permeability of concrete and its relation to carbonation." Construction and Building Materials, 85, 30-37.

Shiire, T. and Kasami, H., (1989). "Concrete quality management." Concrete Journal, 27(4), 41-47. (in Japanese)

Stefanoni, M., Angst, U. and Elsener, B., (2018). "Corrosion rate of carbon steel in carbonated concrete - A critical review." Cement and Concrete Research, 103, 35-48.

Suzuki, K., Tanabe, I. and Eguchi, K., (1984). "Quality control of concrete production in nuclear power plant construction." Summaries of Technical Papers of Annual Meeting of Architectural Institute of Japan, 59, 367-368. (in Japanese)

Tanaka, M., Nakamura, K., Kobayashi, K. and Okamoto, K., (1999). "Survey of concrete in nuclear power plants (for concrete using crushed sand alone as fine aggregate)." Summaries of Technical Papers of Annual Meeting of Architectural Institute of Japan, 1999, 305-306. (in Japanese)

Tanaka, M., Tanji, I., Hirotani, K. and Iwakami, S., (2006). "Study of concrete quality management in new construction of Unit 1 of Higashidori Nuclear Power Plant." Concrete Journal, 44(9), 143-146. (in
Japanese)

Tanji, I., Okada, Y. and Odaka, K., (1999). "Methods of shortening construction period of Onagawa Nuclear Power Plant Unit 3.” Concrete Journal, 37(12), 34-37. (in Japanese)

Ueda, K., Kimura, M. and Ohta, S., (1989). "The reactor building structural works at site 'Monju', the prototype fast breeder reactor." Concrete Journal, 27(10), 34-41. (in Japanese)

Umeki, Y., Sawada, S., Mitsugi, S., Maenaka, T. and Takiguchi, K., (2016). "Outline of guidelines for maintenance and management of structures in nuclear facilities." Journal of Advanced Concrete Technology, 14(10), 643-663.

Yamamoto, M., Setogawa, S. and Kimura, M., (1991). "Concrete works in the construction of PCCVs in Unit No. 3 and No. 4 at Ohi Nuclear Power Station." Concrete Journal, 29(2), 27-40. (in Japanese)

Yonashiro, A., Kimura, M. and Takemoto, Y., (1986). "Construction of concrete frame of PCCV at Japan Atomic Power Company's Tsuruga Unit 2." Journal of Prestressed Concrete (Special Issue), 28, 43-55. (in Japanese)

Yonezawa, T., Oshida, F., Honma. D., Yamaguchi, Y., Okamoto, H. and Nakao, M., (2014). "Corrosion rate of steel reinforcement after carbonation of concrete." Journal of Structural and Construction Engineering (Transactions of AIJ), 79(704), 1405-1414. (in Japanese) 